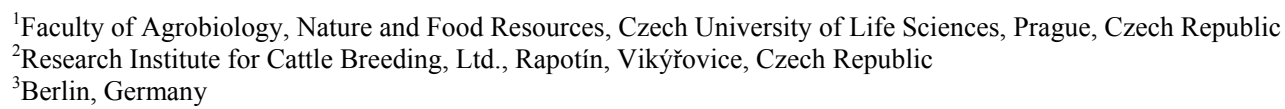

\title{
Analysis of population and heterosis effects in crossbred cattle of Czech Fleckvieh and Beef Simmental parentage for growth traits
}

\begin{abstract}
Genetic effects, e.f. population and heterosis effects have been estimated for: Czech Fleckvieh, Beef Simmental and various types of their crosses produced in beef cow-calf operations. The best genetic-statistical model was chosen for the analyze of these effects. The fallowing traits were analyzed: birth weight, weights at 210 and at 365 days of age as well as average daily gains between birth and 210 days, between 210 and 365 days and between birth and 365 days of age. Parameters for all the traits were estimated by the method of least squares means with fixed effects year of birth, herd, sex, type of birth (single or multiple), age of dam and genotype. Genetic models involved the means and two to four crossbreeding effects: i.e. direct and maternal population effect and direct and maternal heterosis effect. The results showed that the genetic model including the mean and all four crossbreeding effects was more accurate and advantageous that the others. For all growth traits crossbreds exceeded both purebred populations. Positive values were estimated for most direct and maternal population effects. Direct and maternal heterosis effects in global showed negative values.
\end{abstract}

Keywords: beef cattle, crosses, growth, population effects, heterosis, population model

\section{Zusammenfassung}

Titel der Arbeit: Analyse der Populations- und Kreuzungseffekte für Wachstumsparameter bei Kreuzungen der Rassen Czech Fleckvieh und Simmental

Für Tschechisches Fleckvieh, Simmental und ihre Kreuzungen aus Mutterkuhhaltung wurden die Populationsund Kreuzungseffekte geschätzt. Das beste genetisch-statistische Modell wurde für die Analyse dieser Effekte angepasst. Folgende Merkmale wurden analysiert: Geburtsgewicht, 210- und 365-Tage Gewicht, durchschnittliche tägliche Zunahme von der Geburt bis zu 210 Tagen, von 210 bis zu 365 Tagen und von der Geburt bis zu 365 Tagen. Die Parameter für die einzelnen Merkmale wurden mit der Methode der kleinsten Quadrate unter Einbeziehung der fixen Effekte Geburtsjahr, Herde, Geschlecht, Geburtstyp (Einling oder Zwilling), Alter der Mutter und Genotyp geschätzt. Die genetischen Modelle umfassten das Mittel und zwei bis vier Kreuzungseffekte: den direkten und maternalen Populationseffekt und die direkte und maternale Heterosis. Die Ergebnisse zeigen, dass die genetischen Modelle mit dem Mittel und allen vier Kreuzungseffekten genauer und vorteilhafter waren als die anderen Modelle. Die Ergebnisse zeigen für alle Wachstumsmerkmale, dass die Kreuzungen die beiden Reinrassen übersteigen. Die positiven Werte wurden für die meisten direkten und maternalen Populationseffekte geschätzt. Die direkten und maternale Kreuzungseffekte waren global negativ.

Schlüsselwörter: Fleischrinderrassen, Kreuzungen, Wachstum, Populationseffekte, Kreuzungseffekte, Populationsmodell

\section{Introduction}

As in pigs, sheep, poultry and rabbits for meat production, also in cattle breeding various systems of crossbreeding and various combinations of breeds within these systems are used to ensure meat production of high quality, adequate quantities and maximum economic effects. Various crossbreeding systems are known and in terms of 
efficiency and production they are often more important than the pure breeding sector. In addition to population and heterosis effects, the complement of maternal by paternal breed is often exploited. Analyses of breed efficiency of beef cattle and its crosses are important for getting information about genetic mechanisms influencing hybridization of genotypes for different purposes, finding an optimal combination of breeds for future hybridization programs and comparing profitability of various selections and crossbreeding strategies using the same breeds (SÖLKNER, 1993). Estimation of crossbreeding parameters is important for determining efficiency of the hybridization system and for fully utilizing of genetic differences between the breeds. Knowing extent and direction of genetic effects of the purebreds and of two-breed hybrids is the base for estimation of efficiency of multi-breed crosses, which are very difficult to test. In beef cattle populations it is impossible to predict the exactly effects of hybridization accurately due to small population size and missing reciprocal hybrids. Therefore is necessary to carry on specific experiments, which allow us more accurate prediction of the crossbreeding effects.

Analysis of breed and crosses efficiency and prediction of crossbreeding effects in beef cattle have been focused on by many authors: JAKUBEC (1993), WOLF and HERRENDORFER (1993), DISTL et al. (1998), MIELENZ et al. (2003), ROSO et al. (2005) and HEROLD et al. (2007) and with particular respect to Czech Fleckvieh and Beef Simmental RODRIGEZ-ALMEIDA et al. (1997), FRELICH et al. (1998), ŠUBRT et al. (2006) and LINK et al. (2007).

The aim of this work was to estimate direct and maternal population and heterosis effects for the following growth indicators: birth weight, weaning weight at 210 days of age, weight at 365 days of age, average daily gains between birth and 210 days of age, between birth and 365 days of age and between 210 and 365 days of age, and select a suitable model for the estimation of population and heterosis effects. Breeds involved are: Czech Fleckvieh, Beef Simmental and their hybrids.

\section{Material and methods}

The data of 2719 animals of Czech Fleckvieh (C100) - dual-purpose cattle of Simmental type (medium to large body size), Beef Simental (C0) and three of their hybrid genotypes - 75\% Czech Flecvieh (C75), 50\% Czech Flecvieh (C50) and 25\% Czech Flecvieh (C25) - reared in the Czech Republic in the period of 1994 to 1999 were included in the analysis. Carried out as part of a specific experiment in collaboration with the Research Institute for Cattle Breeding in Raponit. Due to use natural service in the herds evaluating herd bulls in particular years and herds was not possible. As a part of this specific experiment, the animals of the particular breeds and their hybrids were bred together in the herds. The herds were placed in various climatic and production areas of the Czech Republic and included a wide range from farms in lowland areas, not typical for breeding beef cattle to farms in mountain areas. The calves were reared and fed from birth to weaning in cow-calf operations with low intensity. After weaning the animals were kept in stables with medium intensity of feeding (gain of $750 \mathrm{~g}-1000 \mathrm{~g} / \mathrm{head} /$ day), i.e. under field conditions to the age of 365 days. Birth weight, weaning weight at 210 days and weight at 365 days and average daily gains from birth to the 210 days, from 210 and 365 days and from birth to 365 days 
and were analyzed by the method of least squares means using a GLM procedure of the statistical package SAS (SAS, 2004) using the statistical model:

$$
\mathrm{y}_{\mathrm{ijk} k \mathrm{mno}}=\mu+\mathrm{Y}_{\mathrm{i}}+\mathrm{H}_{\mathrm{j}}+\mathrm{S}_{\mathrm{k}}+\mathrm{N}_{\mathrm{l}}+\mathrm{A}_{\mathrm{m}}+\mathrm{G}_{\mathrm{n}}+\mathrm{e}_{\mathrm{ijklmno}}
$$

where: $y_{i j k l m n o}-$ observation, $\mu$ - overall mean, $Y_{i}$ - fixed effect of the $i^{\text {th }}$ year of birth (1994-1999), $H_{j}$ - fixed effect of the $j^{\text {th }}$ herd, $S_{k}$ - fixed effect of the $k^{\text {th }}$ sex (bull, heifer), $\mathrm{N}_{1}$ - fixed effect of the $1^{\text {th }}$ number of calves (single, twins), $A_{m}$ - fixed effect of the $m^{\text {th }}$ age of the mother, $G_{n}$ - fixed effect of the $n^{\text {th }}$ genotype $(C 100, C 75, C 50, C 25$ and $\mathrm{C} 0), \mathrm{e}_{\mathrm{ijklmn}}$ - random residual error.

The differences between the least squares means were tested at the significance level (error probability) of $\mathrm{p}<0.05, \mathrm{p}<0.01, \mathrm{p}<0.001$.

For estimation of particular crossbreeding effects an additive-dominant model was used (JAKUBEC, 1993), which is based on intraloci interaction. The calculations were performed according to methods suggested by MATHER and JINKS (1971) and JAKUBEC (1985).

The general model for prediction of the crossbreeding effects was:

$$
\bar{P}=\mu+\left(a_{1}-a_{2}\right) g+\left(a_{1}-a_{2}\right) g^{M}+d_{12} h+d_{12} h^{M}
$$

where: $\bar{P}$ - phenotypic means of the traits in the population, $\mu$ - overall mean, $\mathrm{a}_{\mathrm{i}}-$ gene proportion of the $i^{\text {th }}$ starting population, $d_{i j}$ - probability that there is one allele from the $i^{\text {th }}$ and from the $\mathrm{j}^{\text {th }}$ population in a random locus of an arbitrary member of the population, $\mathrm{g}-$ direct population effect, $\mathrm{g}^{\mathrm{M}}-$ maternal population effect, $\mathrm{h}-$ direct heterosis effect, $\mathrm{h}^{\mathrm{M}}$ - maternal heterosis effect.

The crossbreeding parameters were predicted by the method of weighted least squares. Table 1 shows predicted values of crossbreeding effects that are used as a basis for a structural matrix $\mathrm{X}$, where genotype $\mathrm{C} 100$ assumes the value of -1 and genotype $\mathrm{C} 0$ the value of +1 . We have also tested a suitability of a three-parameter $\left(\mu, g^{*}, h^{*}\right)$ and five-parameter $\left(\mu, g, h, g^{\mathrm{M}}, h^{\mathrm{M}}\right)$ model.

Significance of differences between the observed and predicted utility values was tested by a chi square-congruence test ( $\chi 2$, KAPS and LAMBERSON, 2004).

Table 1

Expected rates of cross-breeding effects $(\mathrm{C} 100<\mathrm{C} 0)($ Erwarteter Anteil der Kreuzungseffekte $[\mathrm{C} 100<\mathrm{C} 0])$

\begin{tabular}{llllll}
\hline Genotyp & $\mu$ & $\mathrm{g}$ & $\mathrm{h}$ & $\mathrm{g}$ & $\mathrm{h}^{\mathrm{M}}$ \\
\hline C100 & 1 & -1 & 0 & -1 & 0 \\
C75 & 1 & -0.5 & 0.5 & -1 & 0 \\
C50 & 1 & 0 & 1 & -1 & 0 \\
C25 & 1 & 0.5 & 0.5 & 0 & 1 \\
C0 & 1 & 1 & 0 & 1 & 0 \\
\hline
\end{tabular}

Results and discussion

Estimated overall means, standard deviations (SD) and variation coefficients (CV\%) for the observed traits of genotypes were shown in Table 2. Variation coefficients (CV\%) for gains from birth to 210 days and from 210 days to 365 days of age were higher than variation coefficients for individual weights. Due to the higher variation of gains compared to weights their use as selection criteria will result in more efficient selection, of the heritability estimations of KECLÍK et al. (2003) for Czech Fleckvieh are applied. Therefore the tests for growth in the selections programme of Beef Simmental bulls in now based on average daily gain rather than on weights. 
Table 2

Overall averages, standard deviations (SD) and variation coefficients $(\mathrm{CV})$ for observed traits $(\mathrm{kg})$ in the whole population not regarding individual genotypes (Allgemeine Mittelwerte. Standardabweichungen [SD] und Variationskoeffizienten [CV] für ganze Population ohne Rücksicht auf Genotypen)

\begin{tabular}{lrrrr}
\hline Traits & $\mathrm{n}$ & average & SD & CV\% \\
\hline Weight $(\mathrm{kg})$ & & & & \\
Birth & 2719 & 35.36 & 3.63 & 10.27 \\
210 days & 1837 & 251.03 & 38.71 & 15.42 \\
365 days & 565 & 391.68 & 51.23 & 13.08 \\
Average day gain $(g)$ & & & & \\
Birth-210 days & 1837 & 1025 & 184 & 17.95 \\
Birth-365 days & 565 & 981 & 142 & 14.47 \\
210-365 days & 565 & 814 & 265 & 32.07 \\
\hline
\end{tabular}

\section{Analysis of environmental effects}

Statistical analysis considered the systematic effects of year, birth, herd, sex, type of birth (single or multiple) and age of dam (Table 3). Highly significant differences in year of birth were detected in all observed traits $(\mathrm{p}<0.0001)$. Birth weight and 210 day weight were lowest for the year 1994. The herd effect representing an area and a breeder was highly significant for all characteristics $(\mathrm{p}<0.0001)$.

Table 3

Significance levels of systematic effects (Signifikanz der systematischen Effekte)

\begin{tabular}{lccccccc}
\hline Effects & Levels & BW & WW & YW & ADG-BW & ADG-WY & ADG-BY \\
\hline Year of birth & 6 & $* * *$ & $* * *$ & $* * *$ & $* * *$ & $* * *$ & $* * *$ \\
Herd & 19 & $* * *$ & $* * *$ & $* * *$ & $* * *$ & $* * *$ & $* * *$ \\
Sex & 2 & $* * *$ & $* * *$ & $* * *$ & $* * *$ & $* * *$ & $* * *$ \\
Type of birth & 2 & $* * *$ & $* * *$ & $*$ & $* * *$ & 0.7268 & 0.0718 \\
Age of dam & 16 & 0.0857 & $* * *$ & $* *$ & $* * *$ & $* *$ & $* *$ \\
Genotype & 5 & $*$ & $* * *$ & $* * *$ & $* * *$ & $* * *$ & $* *$ \\
\hline
\end{tabular}

${ }^{*} \mathrm{p}<0.05,{ }^{* *} \mathrm{p}<0.01,{ }^{* * *} \mathrm{p}<0.001, \mathrm{BW}=$ birth weight, $\mathrm{WW}=$ weaning weight (at 210 days of age), $\mathrm{YW}=$ yearling weight, ADG-BW=average daily gain from birth to weaning, $\mathrm{ADG}-\mathrm{WY}=$ average daily gain form weaning to yearling, $\mathrm{ADG}-\mathrm{BY}=$ average daily gain form birth to yearling

Differences between highest and lowest levels were markedly higher for the herd effect than for the other effects and they may be ascribed to differences in management and also to different levels of nutrition in individual herds. High statistical differences between years of birth and between herds were also affected by a sire effect, which could not be separate from the other effects due to the confounding of natural service bulls with herds and years. Bulls were heavier and grew faster compared to heifers $(\mathrm{p}<0.01)$ in all tested areas. Differences in type of birth were significant $(\mathrm{p}<0.05)$ or highly significant $(\mathrm{p}<0.0001)$ in most of the growth traits, except for gain from birth to 365 days and from 210 to 365 days of age. Twins showed lower weights than single calves during the whole period between birth and 365 days. Multiple births are still more profitable than single births, because they produce, in spite of lower growth, more meat per dam. Rising number of calves per one birth and number of bred calves is a possibility of raising the efficiency of meat production. Differences between bulls and heifers and single and twins respectively were conclusions of GOYACHE et al. (2003), KRUPA et al. (2005) and SZABO et al. (2006). Age of dam, except for birth weight, was significant $(p<0.05)$ or highly significant $(p<0.0001)$. Calves of dams of 2 to 5 years of age show higher growth ability, than calves of dams of 5 to 8 years. This is probably caused by higher lactation performance of younger cows as similar to SZABO et al. (2006). On the other hand, KRUPA et al. (2005) reported highest calf for dams between the 5 and 7 years of age. 


\section{Analysis of genotype}

Differences between the genotypes were significant for body weight $(p<0.05)$ and highly significant for weaning weight and yearling weight and for the gains between birth and 210 days, 210 and 365 days as well as between birth and 365 days of age (Table 3). Czech Fleckvieh (C100) showed higher birth weight (31.72 kg) than the other genotypes, but the lowest values in all the other traits (Table 4). The lower proportion of Czech Fleckvieh - down to C25 - were the higher weaning weight and gain from birth to weaning $(274.69 \mathrm{~kg}$ and $1.158 \mathrm{~kg}$, respectively). The highest value in the C25 genotype for birth weight and average daily gains from birth to 210 days may have been due to a full maternal heterosis effect $\left(\mathrm{h}^{\mathrm{M}}\right)$. Average daily gains form 210 to 365 days showed an opposite trend. The higher the rate of Czech Fleckvieh (C75) the higher were the daily gains. Yearling weight and of average daily gain from birth to 365 days varied in dependently on genotype. The highest values for weight at 365 days $(419.50 \mathrm{~kg}$ ) and of average daily gains from birth to 365 days $(1.066 \mathrm{~kg})$, shown in crossbreds C50, expressed the full direct heterosis effect (h). Genotype C75 showed the second highest estimates of birth weight, weight at 365 days and average daily gains from birth to 365 days. The results clearly showed for all growth traits, that crossbreds exceeded both purebred populations.

JAKUBEC (2003) found lower projected values for birth weight $(28.29 \mathrm{~kg}$ ), for weaning weight $(260.72 \mathrm{~kg})$ and for average daily gains form birth to weaning $(1.107$ $\mathrm{kg}$ ) in Beef Simmental. For the other traits estimates of the present study were lower. On the other hand SULLIVAN et al. (1999) and LINK et al. (2007) and FRELICH and VOŘÍŠKOVÁ (1997) published higher estimates for individual growth traits in Beef Simmental and crossbreds of Czech Fleckvieh and beef cattle. Also, JAKUBEC (2003) observed higher values in Czech Fleckvieh, except for weaning weight and average daily gains form birth to weaning, than in the present study.

\section{Analysis of population and heterosis effects}

Estimated population and heterosis effects for all growth traits are shown in absolute and relative values $(\mathrm{C} 100<\mathrm{C} 0)$, both for three $\left(\mu, \mathrm{g}^{*}, \mathrm{~h}^{*}\right)$, and five parameters $(\mu, \mathrm{g}, \mathrm{h}$, $\left.\mathrm{g}^{\mathrm{M}}, \mathrm{h}^{\mathrm{M}}\right)$, in Tables 5 and 6 . This obvious that the overall means for both models, for three and five parameters, are basically the same. The direct population effects and direct heterosis effect in the three-parameter model were higher than for five parameters. This difference was caused by the maternal effect included in direct population and heterosis effects $\left(\mathrm{g}^{*}=\mathrm{g}+\mathrm{g}^{\mathrm{M}}, \mathrm{h}^{*}=\mathrm{h}+\mathrm{h}^{\mathrm{M}}\right)$. Thus in the five-parameter model the estimation of individual heterosis effects was more accurate.

Therefore the five-parameter estimation of heterosis effects is suited better for precise estimation of heterosis effects. These conclusions were in agreement with DEMEKE et al. (2003) who also pointed out that the three-parameter model was not sufficient for estimation of population and heterosis parameters and subsequent evaluation of crossbreds. Therefore, only the five-parameter model will further on be considered.

Positive value were estimated for most direct and maternal $\left(\mathrm{g}, \mathrm{g}^{\mathrm{M}}\right)$ population effects under the five-parameters model. Direct and maternal $\left(\mathrm{h}, \mathrm{h}^{\mathrm{M}}\right)$ heterosis effects in global showed negative values. The direct population effect $(\mathrm{g})$ was positive for all traits except for birth weight with particularly high values for yearling weight and daily gains for all periods. For the maternal population effect $\left(\mathrm{g}^{\mathrm{M}}\right)$ small positive values were estimated for birth and weaning weight but large negative values for the 
Table 4

LSM and their SE of growth indicators for individual genotypes (Least squares Mittelwerte und Standardfehler für Genotypen)

\begin{tabular}{|c|c|c|c|c|c|c|c|c|c|c|c|c|c|c|c|c|c|c|}
\hline & \multicolumn{3}{|c|}{$\mathrm{BW}(\mathrm{kg})$} & \multicolumn{3}{|c|}{ WW (kg) } & \multicolumn{3}{|c|}{ YW (kg) } & \multicolumn{3}{|c|}{ ADG-BW (g) } & \multicolumn{3}{|c|}{ ADG-BY (g) } & \multicolumn{3}{|c|}{ AGG-WY (g) } \\
\hline & $\mathrm{n}$ & LSM & SE & 11 & LSM & SE & 11 & LSM & SE & $\mathrm{n}$ & LSM & SE & $\mathrm{n}$ & LSM & $\mathrm{SE}$ & $\mathrm{n}$ & LSM & SE \\
\hline 100 & 622 & 31.72 & 0.57 & 423 & 2 To.1 & & 132 & 362.32 & & 423 & 1023 & 26 & 132 & 896 & 38 & 132 & 835 & 12 \\
\hline 75 & 351 & 31 . & 0.75 & 312 & 202 & 10.61 & 88 & 41 & 26.15 & 312 & 6 & 51 & 88 & 1062 & 72 & 88 & 1058 & 136 \\
\hline $\mathrm{C} 50$ & 779 & 30.90 & 0.56 & 495 & 265.26 & 5.26 & 138 & 419.50 & 12.42 & 495 & 1116 & 25 & 138 & 1066 & 34 & 138 & 1041 & 65 \\
\hline 25 & 403 & 30.74 & 0.72 & 240 & 274.69 & 8.77 & 83 & 390.44 & 28.28 & 240 & 1158 & 42 & 83 & 988 & 77 & 83 & 981 & 147 \\
\hline 0 & 564 & 30.99 & 0.60 & 367 & 272.30 & 6.07 & 111 & 407.54 & 15.09 & 367 & 1154 & 29 & 111 & 1034 & 41 & 111 & 949 & 79 \\
\hline
\end{tabular}

$\mathrm{BW}=$ birth weight, $\mathrm{WW}=$ weaning weight (at 210 days of age), $\mathrm{YW}=$ yearling weight, $\mathrm{ADG}-\mathrm{BW}=$ average daily gain from birth to weaning, ADG-WY=average daily gain form weaning to yearling, ADG-BY=average daily gain form birth to yearling

Table 5

Estimated crossbreeding effects for growth traits (three-parameter model) (Kreuzungseffekte für Wachstumsmerkmale [Drei-Parameter-Modell])

\begin{tabular}{|c|c|c|c|c|c|}
\hline & \multirow{2}{*}{$\begin{array}{c}\boldsymbol{\mu} \\
\text { absolute }\end{array}$} & \multicolumn{2}{|c|}{$\mathbf{g}$} & \multicolumn{2}{|c|}{$\mathbf{h}$} \\
\hline & & absolute & $\%$ & absolute & $\%$ \\
\hline \multicolumn{6}{|l|}{ Weight (kg) } \\
\hline Birth & 31.32 & -0.38 & -1.2 & -0.48 & -1.5 \\
\hline 210 days & 257.65 & 10.42 & 4.0 & 5.36 & 2.1 \\
\hline 365 days & 384.42 & 20.09 & 5.2 & 34.64 & 9.0 \\
\hline \multicolumn{6}{|l|}{ Gain (g) } \\
\hline Birth-210 days & 1093 & 66 & 6.0 & 30 & 12.8 \\
\hline $210-365$ days & 898 & 48 & 5.4 & 153 & 17.1 \\
\hline Birth-365 days & 966 & 60 & 6.2 & 103 & 10.6 \\
\hline
\end{tabular}

Table 6

Estimated crossbreeding effects for growth traitss (five-parameter model) (Kreuzungseffekte für Wachstumsmerkmale [Fünf-Parameter-Modell])

\begin{tabular}{|c|c|c|c|c|c|c|c|c|c|}
\hline & \multirow{2}{*}{$\begin{array}{c}\boldsymbol{\mu} \\
\text { absolute }\end{array}$} & \multicolumn{2}{|c|}{ g } & \multicolumn{2}{|c|}{$\overline{g^{M}}$} & \multicolumn{2}{|c|}{ h } & \multicolumn{2}{|c|}{$\mathbf{h}^{\mathbf{M}}$} \\
\hline & & absolute & $\%$ & absolute & $\%$ & absolute & $\%$ & absolute & $\%$ \\
\hline \multicolumn{10}{|l|}{ Weight (kg) } \\
\hline Birth & 31.35 & -1.37 & -4.4 & 1.02 & 3.2 & 0.55 & 1.8 & -0.20 & -0.6 \\
\hline 210 days & 259.67 & 10.16 & 3.9 & 2.48 & 1.0 & 8.86 & 3.4 & -21.49 & -8.3 \\
\hline 365 days & 385.90 & 54.58 & 14.1 & -32.94 & -8.5 & 2.22 & 0.6 & -23.86 & -6.2 \\
\hline \multicolumn{10}{|l|}{ Gain (g) } \\
\hline Birth-210 days & 1091 & 177 & 16.2 & -114 & -10.4 & -84 & -7.7 & 21 & 1.9 \\
\hline 210-365 days & 899 & 233 & 25.9 & -183 & -20.4 & -29 & -3.3 & -20 & -2.2 \\
\hline Birth-365 days & 970 & 166 & 17.1 & -102 & -10.5 & 2 & 0.2 & -66 & -6.8 \\
\hline
\end{tabular}

other traits. The largest values resulted in average daily gain form weaning to yearling, the direct population effect $(25.9 \%)$ being positive and the maternal population effect being negative $(-20.4 \%)$. This is due to the maternal population effect witch as an environmental effect for the calf influences the calf's ability to grow. It is hence a quantification of maternal ability, mainly milk production, which influences growth of the calf only unit weaning ( 210 days of age) and is not important there after $(\mathrm{KOCH}$, 1972). CUNDIFF (1972) reported that maternal effects were as important as direct effects during the early preweaning development and that they got smaller as the calf was growing up. The overall negative absolute value of direct maternal effects is caused by a high negative absolute value of yearling weight. Negative values of maternal population effects were also published by SKRYPZEK et al. (2000) for Beef Simmental and Hereford. The direct heterosis effect (h) was positive except for small negative values for average daily gains from birth to weaning and weaning to one year 
of age. Positive values were in agreement with most other authors for crossbreds of Beef Simmental and other breeds (COMERFORD et al., 1988, DEMEKE et al., 2003). The largest direct heterosis effect estimated for average daily gains from birth to weaning and was negative $(-7.74 \%)$. The maternal heterosis effect $\left(\mathrm{h}^{\mathrm{M}}\right)$ on the contrary was negative for all traits, except for average daily gain from birth to weaning, with the largest value for weaning weight $(-8.3 \%)$. This value was negative just as the direct heterosis effect. The weaning weight and the yearling weight provide large negative values which influence the overall absolute value of maternal heterosis effect. McDONALD and TURNER (1972) stated that negative values the maternal heterosis effect for weaning weight demonstrated the advantage of crossbred dams, mainly when bulls were used which caused higher birth weight of calves. On the other hand, LAMB et al. (1992) described that purebred dams required less energy compared to crossbred dams, and therefore the crossbred dams might shown lower lactation yield when the source of energy was limited. LAMB et al. (1992) also reported crossbred dams to produce more calves with higher weight and so to compensate higher energetical requirements. In total they require therefore lower energetical input per production unit than purebred dams.

Based on estimates of individual crossbreeding effects expected means for individual traits and genotypes were calculated. These expected means were compared to observed means (Table 7). Differences between expected and observed means were tested by a congruence test $(\chi 2)$ and were found to be insignificant in all the cases (from $\mathrm{P}>0.2$ to $\mathrm{P}>0.9$ ), which confirmed the fact that the additive-dominant model was appropriate.

Table 7

Expected and observed averages of individual traits and genotypes $(\mathrm{C} 100<\mathrm{S} 100)$ (Erwartete und beobachtete Mittelwerte einzelner Merkmale und Genotypen $[\mathrm{C} 100<\mathrm{S} 100])$

\begin{tabular}{lcccccccccccr}
\hline & \multicolumn{2}{c}{ BW $(\mathrm{kg})$} & \multicolumn{2}{c}{ WW (kg) } & \multicolumn{2}{c}{ YW (kg) } & \multicolumn{2}{c}{ ADG-BW (g) } & \multicolumn{2}{c}{ ADG-WY (g) } & \multicolumn{2}{c}{ ADG-BY (g) } \\
& Exp. & Obser. & Exp. & Obser. & Exp. & Obser. & Exp. & Obser. & Exp. & Obser. & Exp. & Obser. \\
\hline C100 & 31.71 & 31.72 & 247.23 & 246.17 & 364.33 & 362.32 & 910 & 900 & 1080 & 1020 & 850 & 840 \\
C75 & 31.27 & 31.22 & 255.12 & 262.97 & 391.69 & 418.97 & 990 & 1060 & 1080 & 1110 & 950 & 1060 \\
C50 & 30.84 & 30.90 & 263.01 & 265.26 & 419.05 & 419.5 & 1070 & 1070 & 1120 & 1120 & 1050 & 1040 \\
C25 & 30.89 & 30.74 & 265.54 & 274.69 & 411.78 & 390.44 & 1050 & 990 & 1140 & 1160 & 1000 & 980 \\
C0 & 30.94 & 30.99 & 268.07 & 272.30 & 404.50 & 407.54 & 1030 & 1030 & 1160 & 1150 & 0950 & 950 \\
\hline
\end{tabular}

$\mathrm{BW}=\mathrm{Birth}$ weight, $\mathrm{WW}=$ weaning weight (at 210 days of age), $\mathrm{YW}=$ yearling weight, $\mathrm{ADG}-\mathrm{BW}=$ average daily gain from birth to weaning, ADG-WY=average daily gain form weaning to yearling, $A D G-B Y=$ average daily gain form birth to yearling

Results of this study support the for all growth traits crossbreds exceeded both purebred populations. Positive values were estimated for most direct and maternal population effects. Direct and maternal heterosis effects in global showed negative values.

The results of this investigation show that it is more suitable to use a five-parameter model than a three-parameter model for accurate estimation of crossbreeding effects. Also the additive-dominant model, based on intraloci interaction seamed to be appropriate. It allowed estimation reliable evaluation of expected utility of various genotypes using Czech Fleckvieh and Beef Simmental. Thus it does not seem necessary to use more complex genetic models based on further interloci interactions, i.e. additivity $\times$ additivity, additivity $\times$ dominance, dominance $\times$ dominance, for estimation of crossbreeding effects. Estimation of crossbreeding effects based on more complex models would require a large number of crossbreeding generations, which it is a limiting factor in breeding livestock. 


\section{Acknowledgements}

This work was supported by the Ministry of Education, Youth and Sports of the Czech Republic (Project No. MSM 6046070901) and by the Ministry of Agriculture of the Czech Republic (Project No. QF 3020).

\section{References}

DEMEKE, S.; NESER, F.W.C.; SCHOEMAN, S.J.:

Early growth performance of Bos taurus $\times$ Bos indicus cattle crosses in Ethiopia: estimation of individual crossbreeding effects. J. Anim. Breed. Genet. 120 (2003), 245-257

DISTL, O.; STENSKE, M.; SEELAND, G.:

Estimation of crossbreeding parameters for fertility traits in dairy cattle. Arch. Tierz. 41 (1998), 5-13

COMERFORD, J.W.; BENYSHEK, L.L.; BERTRAND J.K.; JOHNSON M.H.:

Evaluation of performance characteristics in a diallel among Simmental, Limousin, Polled Hereford and

Brahman beef cattle. I. Growth, Hip height and pelvic size. J. Anim. Sci. 66 (1988), 293-305

CUNDIFF, L.V.:

The role of maternal effects in animal breeding: VIII. Comparative aspects of maternal effects. J. Anim. Sci. 35 (1972), 1335-1337

FRELICH, J.; VOŘÍŠKOVÁ, J.:

Fattening performance in bulls-crossbreds of Czech Pied and Black Pied cattle with beef cattle breeds. Czech J. Anim. Sci. 42 (1997), 49-58

FRELICH, J.; VORISKOVA, J.; KUNIK, J.; KVAPILIK, J.:

Fattening ability and carcass value of bulls-crossbreds of Bohemian Spotted catte with beef breeds. Arch. Tierz. Dummerstorf, 41 (1998), 533-544

GOYACHE, F.; FERNÁNDEZ, I.; ROYO L.J.:

Factors affecting actual weaning wieght, preweaning average daily gain and relative growth rate in Asturiana de los Valles beef cattle. Arch. Tierz. 46 (2003). 235-243

HEROLD, P.; SNELL, H.; TAWFIK, E.S.:

Growth, carcass and meat quality parameters of purebred and crossbred goat kids in extensive pasture. Arch. Tierz. 50 (2007), 186-196

JAKUBEC, V.; RAFAY, J.; ŘEHÁČEK, E.; PARKÁNYI, V.:

Analysis of gene action in the control of body weight from birth to 84 days of age in the rabbit. Z. Tierz. Züchtungsbio. 102 (1985), 285-291

JAKUBEC, $\mathrm{V}$ :

General model for genetic effect in animal breeding. Czech J. Anim. Sci. 38 (1993), 861-872

JAKUBEC, V.; SCHLOTE, W.; ŘÍHA, J.; MAJZLÍK I.:

Comparison of growth traits of eight beef cattle breeds in Czech Republic. Arch. Tierz. 46 (2003), 143-153

KAPS, M.; LAMBERSON, W.:

Biostatistics for Animal Science. CABI Publishing. UK (2004)

KECLÍK, R.; FRELICH, J.; BOUŠKA, J.; ŠTÍPKOVÁ, M.; MARŠÁLEK, M.; KUČERA, J.;

Evaluation of bull growth at a cattle progeny testing station in relation to parents' genotype. Czech $\mathrm{J}$. Anim. Sci. 48 (2003), 1-11

KOCH, R.M.:

The role of maternal effects in animal breeding: VI. Maternal effects in beef cattle. J. Anim. Sci. 60 (1972), 1316-1323

KRUPA, E.; ORAVCOVÁ, M.; POLÁK, P.; HUBA, J.; KRUPOVA, Z.: Factors affecting growth traits of beef cattle breeds raised in Slovakia. Czech J. Anim. Sci. 50 (2005), 14-21

LAMB, M.A.; TESS, M.W.; ROBISON, O.W.:

Evaluation of mating systems involving five breeds for integrated beef production systems: I. Cow-calf segment. J. Anim. Sci. 70 (1992), 689-699

LINK, G.; WILLEKE, H.; GOLZE, M.; BERGFELD, U.:

Fattening- and slaughter performance of bulls and heifers of beef breeds and the cross breed German Angus $\times$ Simmental. Arch. Tierz. 50 (2007), 356-362

McDONALD, R.P.; TURNER, J.W.:

Estimation of maternal heterosis in preweaning traits of beef cattle. J. Anim. Sci. 35 (1972), 1146-1154

MATHER, K.; JINKS, J.L.:

Biometrical genetics. Chapman and Hall Ltd., London (1971)

MIELENZ, N.; WENSCH-DORENDORF, M.; SCHÜLER, L.:

Optimierung von Zuchtstrukturen einer Zweilinienkreuzung - Eine Monte-Carlo Studie. Arch. Tierz. 46 (2003), 293-303 
RODRIGEZ-ALMEIDA, F. A.; VAN VLECK, L. D.; GREGORY, K. E.:

Estimation of direct and maternal breed effects for prediction of expected progeny differences for birth and weaning weights in three multibreed populations. J. Anim. Sci. 75 (1997), 1203-1212

ROSO, V.M.; SCHENKEL, F.S.; MILLER, S.P.; WILTON, J.W.:

Additive, dominance, and epistatic loss effects on preweaning weight gain of crossbred beef cattle from different Bos taurus breeds. J. Anim. Sci. 83 (2005), 1780-1787

SAS:

SAS/STAT ${ }^{\circledR}$ 9.1 User's Guide. Cary, NC: SAS Institute Inc. (2004)

SKRYPZECK, H.; SCHOEMAN, S.J.; JORDAAN, G.F., NESER F.W.C.:

Estimates of crossbreeding parameters in a multibreed beef cattle crossbreeding project. S. Afr. J. Anim. Sci. 30 (2000), 193-203

SÖLKNER, J.:

Choice of optimality criteria for the design of crossbreeding experiments. J. Anim. Sci. 71 (1993), 2867-2873

SULLIVAN, P.G.; WILTON, W.J.; MILLER, S.P.; BANKS, L.R.:

Genetic trends and breed overlap derived from multiple-breed genetic evaluations of beef cattle for growth traits. J. Anim. Sci. 77 (1999), 2019-2027

SZABO, F.; NAGY, L.; DAKAY, I.; MARTON, D.:

Effects of breed, age of dam, birth season and sex on weaning weight of beef calves. Liv. Prod. Sci. 103 (2006), 181-184

ŠUBRT, J.; FILIPČÍK, R.; ŽUPKA, Z.; FIALOVÁ, M., DRAČKOVÁ, E.:

The content of polyunsaturated fatty acids in intramuscular fat of beef cattle in different breeds and crossbreds. Arch. Tierz. 49 (2006), 340-350

WOLF, J.; HERRENDORFER, G.:

Considerations on the definition of crossbreeding parameters. Arch. Tierz. 36 (1993), 663-677

Received: 2008-04-23

Accepted: 2008-05-07

Authors:

Ing. LUBOŠ VOSTRÝ, Ph.D.*

Prof. Ing. VÁCLAV JAKUBEC, DrSc.

Doc. Ing. Mgr. IVAN MAJZLÍK, CSc.

Czech University of Life Sciences Prague

Faculty of Agrobiology, Food and Natural Resources

Department of Genetics and Breeding

Kamýcká 129

16521 Prague 6

Czech Republic

Prof. Dr. WERNER SCHLOTE

10099 Berlin

Germany

Ing. MAREK BJELKA, Ph.D.

Ing. JIŘI BEZDÍČEK, Ph.D.

Research Institute for Cattle Breeding, Ltd.

Výzkumníků 267, Rapotín

78813 Vikýřovice

Czech Republic

*Corresponding author

email: vostry@af.czu.cz 